\title{
PELATIHAN JARINGAN UNTUK GURU DAN SISWA SMK AL KAAFFAH KEPANJEN KABUPATEN MALANG
}

\author{
Rini Agustina ${ }^{1^{*}}$ Dodit Suprianto $^{2}$ \\ ${ }^{1}$ Program studi Sistem Informasi, Universitas Kanjuruhan Malang \\ ${ }^{2}$ Jurusan Teknik Informatika, Politeknik Negeri Malang \\ *Email Korespondensi: riniagustina@unikama.ac.id
}

\begin{abstract}
ABSTRAK
Jaringan komputer diperlukan untuk memungkinan penggunanya dapat melakukan komunikasi satu sama lain dengan mudah. Selain itu, peran jaringan komputer sangat diperlukan untuk mengintegrasi data antar komputer-komputer client sehingga diperoleh suatu data yang relevan. Jaringan komputer tidak hanya diperlukan oleh lingkungan perusahaan tetapi juga diperlukan dilingkungan Sekolah. SMK Al Kaffah Malang yang telah memanfaatkan sistem Jaringan saat ini merasa belum optimal karena seringkali masih memindahkan data secara manual dari komputer satu ke yang lainnya, ataupun dari gedung yang satu ke gedung lainnya. Kepala Sekolah merasa memerlukan manajemen pengelolaan sistem jaringan sehingga pertukaran informasi dan data lebih cepat dilakukan. Solusi yang ditawarkan adalah memberikan pelatihan sistem jaringan. untuk mempercepat kerja dan kinerja civitas sekolah. Pelaksanaan pelatihan ini dinyatakan berhasil sesuai tujuan dan target. Peserta termotivasi secara aktif dalam mengikuti kegiatan sampai tuntas. Kerjasama yang berkesinambungan sangat diharapkan untuk meningkatkan kualitas layanan sekaligus hubungan baik antara Universitas Kanjuruhan Dan Pihak Sekolah.
\end{abstract}

Kata kunci : Pelatihan Jaringan, SMK Al Kaffah, Abdimas, Manajemen

\begin{abstract}
A computer network is needed to enable users to communicate with each other easily. In addition, the role of computer networks is needed to integrate data between client computers so that relevant data is obtained. Computer networks are not only needed by the company environment but are also needed in the school environment. Al Kaffah Malang Vocational School, which has utilized the current network system, is not yet optimal because it often transfers data manually from one computer to another, or from one building to another building. The Principal feels the need for network management so that the exchange of information and data was faster. The solution offered is to provide network training system. to accelerate the work and performance of the school community. The training was declared successful according to the objectives and targets. Participants are actively motivated in participating in the activity to the end. Continuous cooperation is highly expected to improve the quality of service as well as good relations between Kanjuruhan University and the School.
\end{abstract}

Keywords: Network Training, Al Kaffah Vocational School, Abdimas, Management

\section{PENDAHULUAN}

Penggunaan jaringan komputer merupakan salah satu fungsi dari komputer yang paling banyak digunakan dan juga diaplikasikan, baik secara lokal maupun luas seperti penggunaan internet. Jaringan komputer sendiri pada dasarnya merupakan kondisi dimana dua atau lebih komputer saling terhubung ke dalam sebuah jaringan tertentu, dimana setiap komputer kemudian dapat saling berbagai satu sama lain. Seperti melakukan proses transfer data informasi, dan juga berbagai macam sumber daya dengan menggunakan satu jaringan saja (Agustina, 2017; Amalia, 2018; Ramdhanivera, 2016).

Prinsip kerja jaringan komputer itu sendiri mengfokuskan untuk menghubungkan semua komputer di berbagai tempat satu dengan yang lainnya. Oleh sebab itu penggunaan manfaat jaringan komputer menjadi salah satu tujuan seseorang menggunakan perangkat 
komputer, terlebih untuk menyimpan data dan penyelesaian di hampir semua pekerjaan. Tentu saja jaringan komputer memberikan banyak sekali manfaat bagi kehidupan manusia.

SMK Al Kaffah memiliki kebutuhan untuk selalu menggunakan sistem jaringan komputer, yang diperlukan unutk mempercepat arus informasi, Mempermudah komunikasi antar individu, Mempercepat proses pengiriman data dan juga sumberdaya. Sistem jaringan yang ada saat ini belum dioptimalkan karena kurangnya pengetahuan dalam pengelolaan sistem jaringan. Sumberdaya pengelola informasi dan Jaringan di SMK Al-Kaffah belum memahami bagaimana pengelolaan sistem jaringan dengan baik sehingga banyak pekerjaan terganggu terkait penggunaan teknologi informasi dan jaringan (Staf, 2012; Febpasundan, 2018; SMK Al Kaffah, 2019).

Dalam mendukung Tri Dharma Perguruan Tinggi yaitu pendidikan, penelitian dan pengabdian kepada masyarakat dan melihat Sumber Daya Manusia di masyarakat khususnya di lingkungan SMK Al Kaffah kepanjen Kota Malang yang dirasa kurang memiliki pengetahuan dasar mengenai sistem jaringan yang sangat diperlukan oleh guru sekaligus siswa dalam mengelola kebutuhan informasi di sekolah (SMK Al Kaffah, 2019).

Sejalan dengan adanya antusias dari pihak Sekolah SMK Al Kaffah pada pengabdian masyarakat kali ini maka perlu diadakannya sebuah pelatihan jaringan guru dan siswa di lingkungan SMK Al Kaffah Kepanjen Kota Malang. Berdasarkan analisis situasi diatas maka perlu diadakan pelatihan atau training yang mengarah pada praktik langsung sehingga peserta bisa lebih faham dan mengerti tentang penggunaan jaringan komputer secara global seperti: mempercepat arus informasi, mempermudah komunikasi antar individu, mempercepat proses pengiriman cata dan juga sumberdaya, membantu mengkoneksikan beberapa tempat sehingga bisa berkomunikasi.

Solusi yang ditawarkan adalah memberikan pelatihan sistem jaringan. Sedapat mungkin dapat meningkatkan Sumber Daya Manusia Guru dan Siswa dalam memanfaatkan Ilmu Pengetahuan dan Teknologi untuk mempercepat kerja dan kinerja civitas sekolah.

Target yang diharapkan pada pengabdian masyarakat ini sesuai dengan permintaan dari Kepala Sekolah yaitu para Guru dan Siswa mampu mengelola system jaringan di sekolah untuk meningkatkan perfoma dari penggunaan media dan teknologi informasi di sekolah, antara lain : mengetahui dasar sistem jaringan komputer, meningkatkan pemanfaatan dari sistem jaringan, menggunakan sistem jaringan untuk kebutuhan sehari-hari baik dalam pertukaran data maupun untuk kebutuhan koneksi internet dan antar ruangan atau gedung yang memerlukan koneksi jaringan. Serta luaran pelatihan ini berupa sistem koneksi yang ditanamkan pada server sekolah.

\section{METODE}

Jenis Kegiatan pengabdian pada masyarakat ini adalah berbentuk pelatihan dan workshop serta praktik langsung. Dalam pelaksanaanya guru dan siswa diberikan buku materi dan pemateri presentasi di depan dengan peserta langsung praktik sesuai dengan arahan dari pemateri dan kemudian dialog antara pemateri dan peserta kebutuhan yang diperlukan di SMK AL Kaaffah Kepanjen Kota Malang serta alternatif pemecahannya. Hal ini merupakan indikator keberhasilan program yang dilaksanakan.

Pengabdian kepada masyarakat ini dilaksanakan pada Bulan Juni 2018 tepatnya pada tanggal 20. Adapun tempat pelaksanaannya dilakukan di Ruang lab SMK AL Kaaffah Kepanjen Kota Malang. Sedangkan materi yang akan disampaikan pada pelatihan dan workshop ini adalah materi system jaringan sesuai dengan permintaan dari sekolah. Adapun jadwal pelaksanan dan rincian materi dapat dilihat pada Tabel 1. 
Tabel 1. Jadwal Pelaksanaan dan Materi Pelatihan dan workshop

\begin{tabular}{|c|l|c|c|}
\hline \multirow{2}{*}{ No } & \multicolumn{1}{|c|}{ Materi } & \multicolumn{2}{c|}{ Pertemuan } \\
\cline { 3 - 4 } & & $\mathbf{1}$ & $\mathbf{2}$ \\
\hline A & Jaringan Dasar & & \\
\hline 1 & Pengenalan Alat-alat Jaringan & & \\
\hline 2 & Pengalamatan Jaringan & & \\
\hline 3 & VSAT & & \\
\hline B & Jaringan Lanjut & & \\
\hline 1 & Konfigurasi Alamat & & \\
\hline 2 & Topologi Jaringan & & \\
\hline
\end{tabular}

\section{HASIL DAN PEMBAHASAN}

Pelatihan yang dilaksanakan selama 2 hari di Lab Aplikasi 1 yang dihadiri oleh 30 orang peserta yang terbagi menjadi 2 tahap, yaitu tahap pertama dimulai pagi pukul $08.00-$ 12.00 dan tahap kedua dimulai pada siang hari pukul 13.00-16.00. Pelatihan ini dimulai dengan pengenalan alat-alat jaringan komputer hingga manajemen server. Pelatihan yang dihadiri para guru dan siswa yang telah didaftarkan sebelumnya ini berjalan lancar dan penuh suasana keakraban serta kekeluargaan.

Hasil dari pelatihan ini ternyata cukup mendapatkan perhatian dan antusias yang baik dari pihak sekolah, guru dan siswa, terbukti dengan adanya penambahan yang cukup signifikan dari jumlah peserta yang sebelumnya telah didaftarkan. Keinginan pihak sekolah ternyata tidak cukup sampai di pelatihan ini saja, tetapi mereka menginginkan pelatihan tersebut diberika lebih lama dan sifatnya terus menerus atau terprogram secara rutin.

Menanggapi keinginan pihak sekolah tersebut tentu saja diperlukan bentuk kerjasama lain untuk dapat mengakomodasi kebutuhan mereka akan informasi yang lebih jauh. Pada pembicaraan selanjutnya akan dikembangkan lagi pendampingan dalam pengelolaan manajemen jaringan.

Faktor pendukung adalah faktor yang dapat mendukung keberhasilan dalam kegiatan pelatihan. Faktor Tersebut terdiri dari :

1. Adanya minat dan keinginan yang tinggi dari peserta dan pihak sekolah sehingga pelatihan ini terlakasana sampai selesai.

2. Adanya tanggapan positif dari pihak sekolah sebagai tempat kegiatan PPM dimana kegiatan yang dilakukan sangat relevan dan sangat bermanfaat bagi guru dan siswa.

Faktor penghambat adalah faktor yang dapat menghambat kelangsungan kegiatan Pengabdian Pada Masyarakat (PPM). Faktor Penghambat tersebut meliputi :

1. Penyebaran undangan yang terlalu mendadak menyebabkan peserta kegiatan tidak tepat dalam pengembalian formulir kegiatan pelatihan untuk menghadiri kegiatan PPM ini.

2. Penentuan jadwal yang cukup padat sehingga sehingga jadwal pelatihan di undur yang awalnya bulan Juli tapi pelaksanaanya bulan Agustus.

\section{Materi Kegiatan}

\section{Pengenalan Jaringan}

\section{A. Prinsip dasar jaringan computer}

Jaringan komputer adalah sekelompok komputer otonom yang dihubungkan satu dengan lainnya dengan menggunakan protokol komunikasi melalui media transmisi atau komunikasi sehingga dapat saling berbagi data / informasi, program-program, penggunaan bersama perangakat keras (seperti printer, hard disk, dsb).

Prinsip dasar dalam sistem jaringan komputer adalah proses pengiriman data atau informasi dari pengirim ke penerima melalui suatu media komunikasi tertentu. Sedangkan tujuan utama dibangunnya suatu jaringan komputer adalah untuk membawa 
data/informasi dari pengirim menuju penerima secara cepat dan tepat tanpa adanya kesalahan melalui media transmisi atau media komunikasi tertentu.

\section{B. Manfaat jaringan komputer}

a. Berbagi pemakaian peralatan dan sumber daya secara bersama-sama.

b. Komunikasi

c. Pemrosesan Terpusat (Tererdistribusi)

d. Keamanan data

\section{Model koneksi dalam jaringan}

Ada dua model koneksi dalam jaringan yaitu :

\section{Peer to peer}

Sistem operasi jaringan model peer to peer memungkinkan seorang user membagi sumber dayanya yang ada dikomputernya, baik itu file data, printer, dll dan mengakses sumber data pada komputer lain.Model ini tidak mempunyai sebuah file server atau sumber daya yang terpusat, seluruh computer mempunyai kemampuan yang sama untuk memakai sumber daya yang tersedia di jaringan.

Kelebihan model jaringan peer to peer antara lain :

a. Tidak terlalu mahal, karena tidak membutuhkan suatu PC yang sepenuhnya berfungsi sebagai server.

b. Mudah dalam instalasi programnya.

Kekurangan model jaringan peer to peer :

a. Tidak terpusat, terutama untuk menyimpan data dan aplikasi

b. Tidak aman, karena tidak terdapat fasilitas pengamanan server.

\section{Client-Server}

Sistem operasi jaringan Client Server memungkinkan jaringan untuk mensentralisasi fungsi dan aplikasi kepada satu atau dua dedicated file server. Sebuah file server menjadi jantung dari keseluruhan system memungkinkan untuk mengakses sumber daya, dan menyediakan keamanan. Workstation-workstation dapat mengambil sumber daya yang ada pada file server.

Kelebihan model jaringan client-server adalah :

a. Terpusat

b. Sumber daya dan keamanan data dikontrol melalui server.

c. Teknologi baru dengan mudah terintegrasi kedalam sistem

d. Keseluruhan komponen dapat bekerjasama (client dan server).

Kekurangan model jaringan client-server adalah :

a. Biaya pengadaan dan operasionalnya mahal

b. Membutuhkan investasi untuk dedicated server

c. Jaringan besar membutuhkan staf ahli sehingga sistem dapat berjalan secara efesien

d. Ketergantungan antar komputer relatif tinggi.

e. Ketika server drop, keseluruhan operasi pada network akan terganggu.

\section{Area jaringan komputer}

Berdasarkan jangkauan area jaringan dan luasan segmen jaringan yang dibangun maka suatu jaringan komputer dapat digolongan menjadi 3 kelompok yaitu :

a. Local Area Network (LAN)

yang termasuk dalam kelompok jaringan ini adalah jika komputer-komputer yang terhubung berada dalam ruangan-ruangan dalam satu gedung.

b. Metropolitan Area Network (MAN)

yang termasuk dalam kelompok MAN adalah jika komputer-komputer yang terhubung berada pada satu gedung dengan gedung yang lain tapi masih dalam satu kota. 


\section{c. Wide Area Network (WAN)}

WAN merupakan pengembangan dari MAN, sehingga komputer-komputer yang terhubung berada pada gedung-gedung yang berada pada kota yang berbeda bahkan berbeda Negara.

Pembangunan WAN melibatkan teknologi telekomunikasi canggih seperti satelit dan gelombang eletronik lainnya. Terciptanya teknologi VSAT dan ISDN dapat menjamin kualitas trasmisi dan informasi jarak jauh yang tidak dimungkinkan dengan sistem pengkabelan biasa.

a. Very Small Aperture Terminal (VSAT)

VSAT disebut juga dengan Stasiun Bumi Mikro (SBM) merupakan antenna stasiun bumi yang kecil. Kemampuan VSAT memang lebih kecil dibandingkan kemampuan satelit yang sesungguhanya namun VSAT sangat murah dibandingkan stasiun bumi umumnya. Jaringan komunikasi VSAT terdiri atas 4 komponen pokok yaitu satelit (Indonesia-Palapa B1, C1), hub station (stasiun pengendali utama), VSAT, dan PES. Keuntungan VSAT antara lain:

1) Dapat menjangkau daerah yang luas (nasional, regional, dan internasional) karena melalui satelit.

2) Dapat dipasang dimana saja (tidak memakan tempat)

3) Tingkat keamanan tinggi

4) Ekonomis (perangkat dan biaya pemakaina murah)

b. Integrated Services Digital Network (ISDN)

Tujuan diciptakannya ISDN adalah untuk meyeragamkan pemakaian jaringan digital dan teknologi switching untuk mengirimkan voice (suara) dan data digital secara bersamaan seperti teletex/telex, videotext, telepon, dll. Di Indonesia penerapan ISDN dikontrol oleh Indosat dan Telkom. Keuntungan ISDN bagi user dengan menyewa satu saluran user dapat menikmati berbagai fasilitas pelayanan transmisi data suara maupun data digital, seperti teletext (peralatan yang memberi layanan informasi melalui channel TV), Facsimile (peralatan untuk transmisi grafis, naskah melalui saluran telpon), videotext (peralatan untuk transmisi data gambar melalui terminal khusus).

\section{Komponen Pembentuk Jaringan}

\section{A. Komponen perangkat keras}

1. Media transmisi, merupakan perangkat yang digunakan untuk menghubungkan antara satu komputer dengan komputer atau peripheral lainnya. Media ini juga berfungsi sebagai distribusi informasi. Media transmisi meliputi berbagai macam bentuk kabel yaitu Coaxial, UTP (Unshielded Twisted Pair), STP (Shielded Twisted Pair), Serat optik.

2. Network Interface Card (NIC), merupakan komponen logika termasuk perangkat keras, perangkat lunak, dan tata cara pengontrolan transmisi data. Contoh dari NIC adalah ARCnet dan Ethernet.

3. Konektor, merupakan peripheral yang menghubungkan media transmisi (kabel) dengan NIC.Contoh konektor adalah T-Connector, RJ 11 \& RJ 45, Duplex style connector atau Epoxy connector.

4. Hub, merupakan media yang akan menerima data dai semua port yang terhubung dan secara otomatis mentransmit data keseluruh port lainnya.

5. Modem, merupakan singkatan dari Modulator Demulator. Pada sisi pengirim modem berfungsi untuk menerjemahkan data dalam bentuk sinyal digital menjadi sinyal analog. Sedangkan sisi penerima modem berfungsi untuk memisahkan data dari frekuensi pembawa dan menerjemahkan data dalam bentuk sinyal analog menjadi sinyal digital. 


\section{B. Komponen perangkat lunak}

Komponen perangkat lunak meliputi sistem operasi jaringan (Network Operating System _ NOS) dan aplikasi. Sistem operasi jaringan merupakan komponen yang penting dalam membangun suatu jaringan karena sistem operasi jaringan berfungsi sebagai pembentuk pola operasi jaringan. Untuk model jaringan peer to peer sistem operasi yang digunakan adalah windows 9X, windows Me, dan novell) sedangkan untuk model jaringan Client Server SO yang digunakan adalah Novell Netaware 3.x, windows NT, 2000 server, Unix, Linux).

\section{Topologi}

Topologi jaringan komputer adalah pola hubungan antarterminal dalam suatu jaringan komputer. Ada 4 macam topologi yang kenal :

1. Topologi bus

Pada topologi bus semua terminal terhubung dengan jalur komunikasi. Setipa informasi yang dikirim diperiksa alamatnya oleh terminal yang dilewati. Jika bukan untuknya, informasi akan dilewatkan sampai menemukan alamat yang benar.

2. Topologi Star

Dalam topologi Star, sebuah terminal pusat bertindak sebagai pengatur dan pengendali semua komunikasi data yang terjadi.

3. Topologi Ring

Topologi ini mirip dengan topologi bus tetapi ke-2 teminal yang berada diujung saling dihubungkan sehingga menyerupai lingkaran. Setiap terminal dalam jaringan saling tergantung sehingga jika terjadi kerusakan pada salah satu terminal maka seluruh jaringan akan terganggu.

4. Topologi Tree

Pada topologi ini hanya ditemui pada jaringan berskala besar karena penambahan terminal tidak mengganggu kinerja seluruh system.

\section{Indikator Keberhasilan}

Hasil yang diperoleh dalam pelatihan ini adalah adanya peningkatan pengetahuan dan informasi peserta mengenai teknologi informasi, serta meningkatnya kinerja dari para aparat dan warga yang berhubungan dengan surat menyurat dan komunikasi.

Meningkatnya keinginan warga sekitar untuk diadakannya pelatihan serupa dan dengan waktu yang lebih lama. Sertifikat pelatihan yang diberikan juga memberikan nilai tambah bagi peserta dan aparat dalam rangka peningkatan keterampilan dan keaktifan warga.

\section{Kontribusi Mitra}

Pada kegiatan ini Pihak sekolah menyediakan sarana pelatihan berupa LCD, Mic, Laptop, Software dan materi pendukung lainnya. Teknis pelaksanaan juga dilakukan oleh pihak desa dengan sangat baik, seperti tempat, waktu dan konsumsi.

Sebagai obyek kegiatan para peserta memberikan dukungan yang cukup baik sehingga sebagai pemateri merasakan adanya feed back yang sangat menyenangkan. Sedangkan sebagai subyek penelitian para peserta bersedia menyediakan waktu dan tenaga sebagai peserta pelatihan serta aktif mengikuti kegiatan.

\section{Keberlanjutan}

Permintaan akan keberlanjutan program pelatihan dari para peserta dan Kepala Sekolah merupakan salah satu alasan kenapa pelatihan ini didesain secara bertahap. Selain sebagai media transfer knowledge juga sebagai media transfer teknologi yang sudah menjadi kewajiban bagi pemateri. 


\section{Dokumentasi Kegiatan}

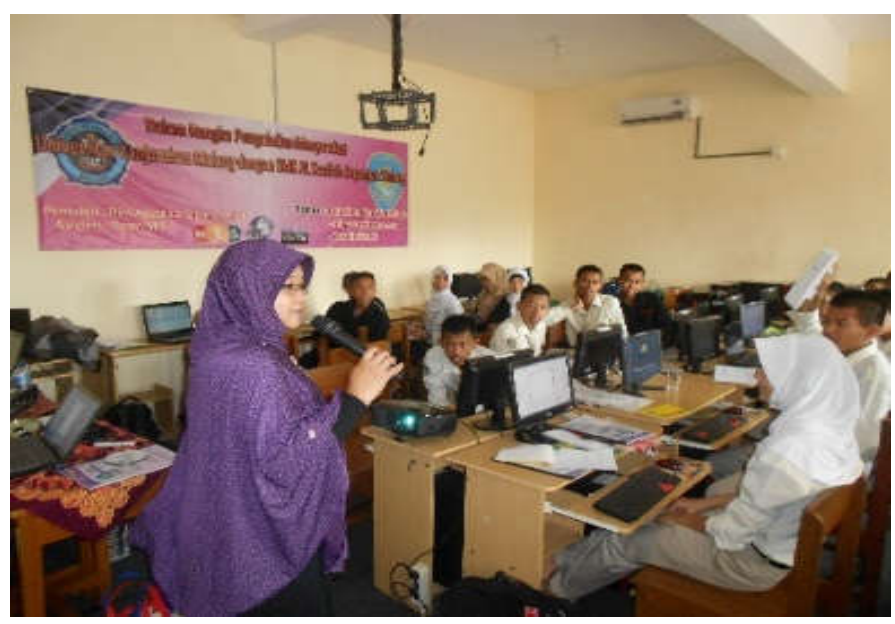

a

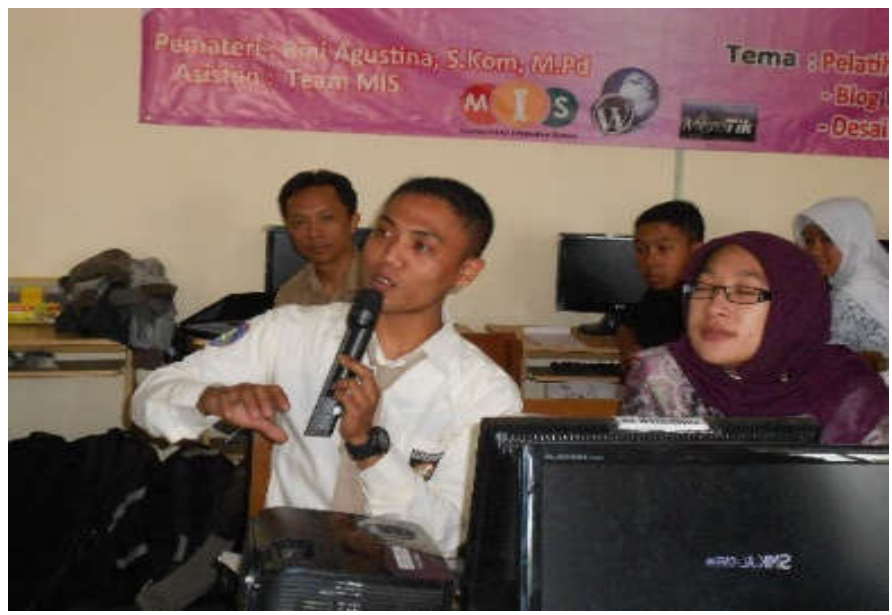

b

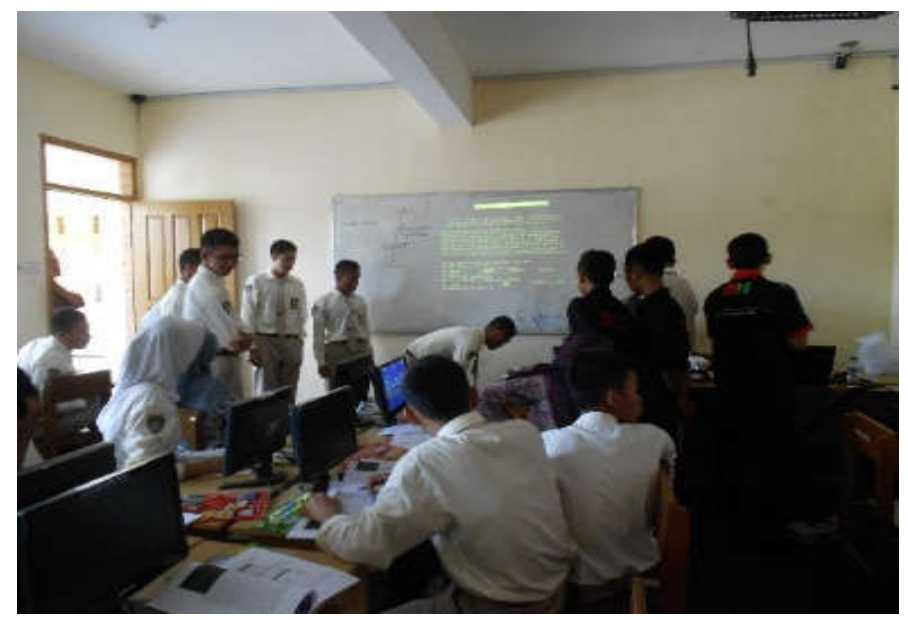

$\mathrm{C}$ 


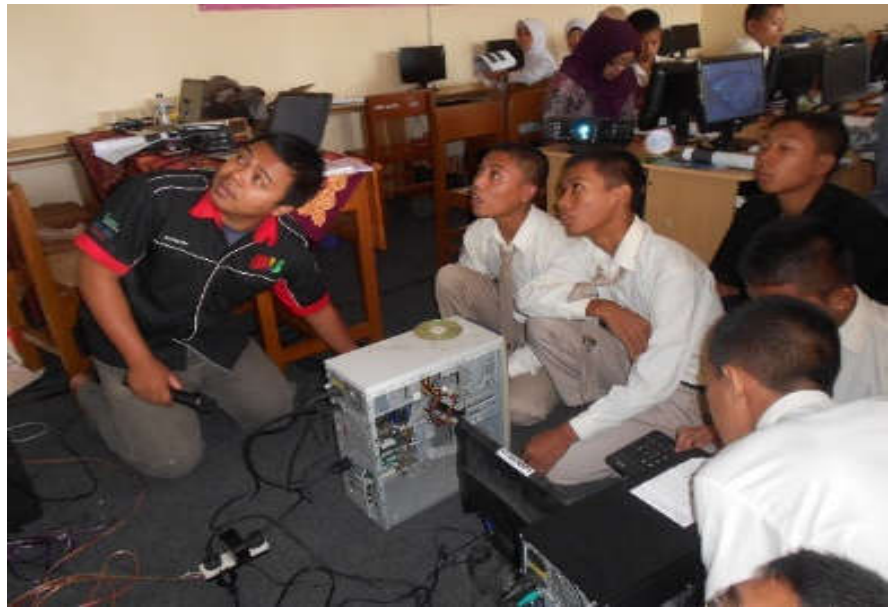

d

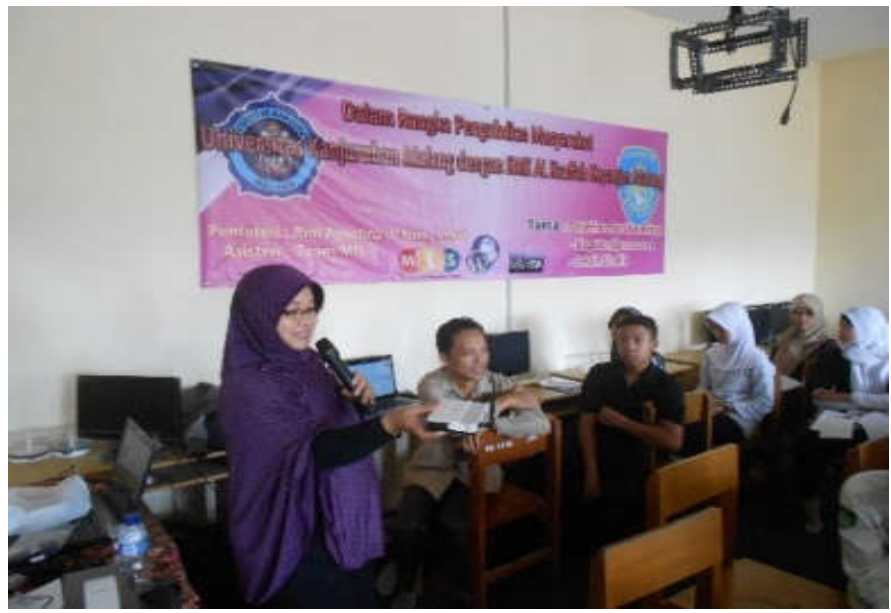

e

Gambar 1a-e. Proses Pelatihan Jaringan untuk Guru dan Siswa SMK Al Kaaffah Kepanjen Kabupaten Malang

\section{DAMPAK DAN MANFAAT}

Kebutuhan teknologi dan informasi dewasa ini merupakan kebutuhan pokok bagi masyarakat. Kemudahan yang ditawarkan dari segi informasi dan komunikasi mempercepat segala aktivitas dan membuat segala sesuatunya lebih muran dan mudah. Karena itu teknologi ini membutuhkan penggunaan jaringan komputer yang pada kegiatan pengabdian masyarakat ini dilakukan pada seluruh guru dan siswa SMK Al Kaafah Kepanjen Kabupaten Malang. Kegiatan ini bertujuan untuk meningkatkan pemahaman mengenai penggunaan jaringan komputer secara global seperti: mempercepat arus informasi, mempermudah komunikasi antar individu, mempercepat proses pengiriman cata dan juga sumberdaya, membantu mengkoneksikan beberapa tempat sehingga bisa berkomunikasi. Kegiatan ini sangat bermanfaat bagi para guru dan siswa sehingga mampu mengaplikasikan sistem jaringan di sekolah maupun di lingkungan sekitarnya.

Pelatihan ini diharapkan dapat meningkatkan kemampuan dan pengetahuan guru dan siswa dalam memanfaatkan Ilmu Pengetahuan dan Teknologi untuk mempercepat kerja dan kinerja civitas sekolah. Selain itu, adanya sistem koneksi yang ditanamkan pada server 
sekolah akan mendukung perancangan dan pembuatan jaringan komputer, penggunaan sistem jaringan untuk kebutuhan sehari-hari baik dalam pertukaran data maupun untuk kebutuhan koneksi internet dan antar ruangan atau gedung yang memerlukan koneksi jaringan. Manfaat yang diharapkan pada pengabdian masyarakat ini sesuai dengan permintaan dari Kepala Sekolah yaitu para Guru dan Siswa mampu mengelola system jaringan di sekolah untuk meningkatkan perfoma dari penggunaan media dan teknologi informasi di sekolah, antara lain : mengetahui dasar sistem jaringan komputer.

\section{KESIMPULAN}

Berdasarkan hasil pengabdian yang telah dilaksanankan maka dapat disimpulkan sebagai berikut, antara lain : pelaksanaan Pengabdian Pada Masyarakat Pelatihan Jaringan di SMK AL Kaaffah Kepanjen Kota Malang berlangsung dengan baik sesuai dengan yang telah direncanakan, pelaksanaan Pengabdian Pada Masyarakat ini dinyatakan berhasil mencapai tujuan dan target. Pelatihan serupa juga pernah dilakukan oleh (Agustina, 2017), yang menyatakan bahwa Pelatihan dapat meningkatkan SDM peserta, serta peserta Pengabdian Pada Masyarakat termotivasi secara aktif dalam mengikuti kegiatan sampai tuntas.

\section{REFERENSI}

Agustina, R. (2017) 'Pelatihan Desain Grafis untuk Perangkat Desa dalam Rangka Peningkatan SDM di Desa Ngawonggo Kecamatan Tajinan Kab. Malang', Jurnal Pengabdian Kepada Masyarakat, 2(1).

Amalia, D, (2018) 'Pengertian Jaringan Komputer dan Manfaatnya', (online) https://idwebhost.com/blog/pengertian-jaringan-komputer-dan-manfaatnya/

Bela, (2015) 'Materi Lengkap Jaringan Komputer, Pengertian, Jenis, Manfaat, Topologi, Protokol', (online) https://jalankuliah.blogspot.com/2017/12/materi-lengkapjaringan-komputer-pengertian-jenis-manfaat-topologi-protokol.html

Ramdhanivera, (2016) 'Pengabdian Pada Masyarakat', (online) https://ramdhaniverablog.wordpress.com/2016/09/20/pengabdian-pada-masyarakat/

Staf, (2012) 'Materi Jaringan Komputer', (online) http://nasautt.blogspot.com/2012/10/materi-jaringan-komputer.html

Febpasundan, (2018) 'Pengabdian Pada Masyarakat, Fakultas Ekonomi dan Bisnis Universitas Pasundan',http://fe.unpas.ac.id/fe app/index.php?TF4HWFNTSlouNTFsJyorKicnZS0p Ej4_PXc8PmkFMzk_ODg_NTwwfzAABgJEKAcUEQgYCgcMGg

SMK Al Kaffah, (2019) 'Profil SMK', (online) http://www.smkalkaaffah.sch.id/html/index.php 